\title{
IMPLEMENTASI SUPERVISI AKADEMIK KEPALA SEKOLAH DALAM MENINGKATKAN MUTU PEMBELAJARAN DI SMA SE-KECAMATAN SIMPANG PEMATANG KABUPATEN MESUJI
}

\author{
Zayyani kontesa $^{1}$, Marzuki Noor ${ }^{2 *}$, Sudirman Aminin. ${ }^{3}$ \\ ${ }^{1,}$ SMK Simpang Pematang \\ 1,2,3 Universitas Muhammadiyah Metro \\ E-mail: $\quad$ kontesazayyani@gmail.com ${ }^{1)}$ \\ marzuki4metro@gmail.com $^{2) *}$ \\ sudirman.am57@gmail.com ${ }^{3)}$
}

\begin{abstract}
Abstrak
Pendidikan adalah usaha manusia untuk menumbuhkan dan mengembangkan potensi-potensi pembawaan baik jasmani maupun rohani sesuai dengan nilai-nilai yang ada didalam masyarakat dan kebudayaan. guru dan kepala sekolah yang secara langsung pada kegiatan pembelajaran dan bertanggung jawab menjamin layanan dalam pendidikan. Guru melalui arahan kepala sekolah sebagai supervisior menjadi titik fokusnya dalam proses pembelajaran, guru dituntut untuk memakai: metode, media, strategi dalam proses pembelajaran, sehingga dapat menghasilkan mutu dalam pembelajaran. Penelitian ini bertujuan untuk mengetahui Pelaksanaan Supervisi Akademik Kepala sekolah yaitu pada perencanaan program supervisi akademik. Teknik pengumpulan data menggunakan metode wawancara, observasi dan dokumentasi. Teknik analisa data menggunakan model reduksi data, penyajian data dan penarikan kesimpulan. Penelitian dilakukan di SMA Se-Kecamatan Simpang Pematang Kabupaten Mesuji. Subjek penelitian adalah kepala sekolah dan guru dan obyek penelitian ini adalah pelaksanaan supervisi akademik kepala sekolah dalam meningkatkan mutu pembelajaran. Hasil penelitian ini menunjukkan bahwa pelaksanaan supervisi akademik kepala sekolah yang mencakup perencanaan/persiapan supervisi akademik, pelaksanaan supervisi akademik dan tindak lanjut hasil supervisi akademik sudah dilakukan dengan baik, mengelola profesional guru yang mencakup penyusunan perangkat pembelajaran, evaluasi hasil proses belajar dan tindak lanjut hasil pembelajaran juga sudah dilakukan dengan baik, namun didalam pelaksanaan pembelajaran yaitu pada penggunaan metode dan media masih kurang efektif.
\end{abstract}

Kata kunci: supervisi akademik, metode pembelajaran

\begin{abstract}
Education is a human effort to grow and develop innate potentials both physically and spiritually in accordance with the values that exist in society and culture. teachers and principals who are directly involved in learning activities and are responsible for ensuring services in the educational process. Teachers through the direction of the principal as a supervisor become the focal point in the learning process, teachers are required to use: methods, media, strategies in the learning process, so as to produce quality in learning. This study aims to determine the implementation of the principal's academic supervision, namely the planning of academic supervision programs. Data collection techniques using interviews, observation and documentation. The data analysis technique uses a data reduction model, data presentation and conclusion drawing. The research was conducted in SMA in Simpang Pematang District, Mesuji Regency. The research subjects are principals and teachers and the object of this research is the implementation of the principal's academic supervision in improving the quality of learning. The results of this study indicate that the implementation of the principal's academic supervision which includes planning/preparing for academic supervision, implementation of academic supervision and follow-up to the results of academic supervision has been carried out well, managing teacher professionals which includes preparation of learning tools, evaluation of learning process results and follow-up on learning outcomes. has also been done well, but in the implementation of learning, namely the use of methods and media is still less effective.
\end{abstract}

Keywords: Academic Supervision, Learning Quality 


\section{PENDAHULUAN}

Pendahuluan minimal harus mengandung state of the art (kajian review literatur Salah satu pilar bangsa yang mempunyai peran strategis untuk membangun karakter bangsa yang bermartabat adalah pendidikan. Pendidikan adalah usaha manusia untuk menumbuhkan dan mengembangkan potensi-potensi pembawaan baik jasmani maupun rohani sesuai dengan nilai-nilai yang ada didalam masyarakat dan kebudayaan. Untuk mencapai hal tersebut diperlukan rangkaian proses dalam pendidikan yang memadai untuk membantu terwujudnya harapan mulia tersebut. Untuk mengimplementasikan tujuan pendidikan, yang perlu ditingkatkan adalah kualitas sumber daya pendidikan terlebih dahulu, sumber daya pendidikan merupakan komponen penting dalam keberlangsungan pendidikan di sekolah. Ada beberapa komponen yang harus diperhatikan dalam sumber daya pendidikan diantaranya guru dan kepala sekolah. Guru dan kepala sekolah merupakan orang yang terjun secara langsung pada kegiatan pembelajaran dan bertanggung jawab menjamin layanan dalam proses pendidikan yang diterima peserta didik sudah sesuai dengan harapan dari pemerintah. Selain itu, guru dan kepala sekolah harus bekerjasama dalamproses pembelajaran guna mencapai mutu pembelajaran yang baik dan sesuai harapan.

Menurut Peraturan Menteri Pendidikan Nasional Nomor 13 Tahun 2007 Tentang Standar Kepala Sekolah, dinyatakan bahwa salah satu kompetensi Kepala Sekolah adalah memiliki kompetensi supervisi,yaitu :1. Merencanakan program supervisi akademik dalam rangka peningkatan profesionalisme guru. 2. Melaksanakan supervisi akademik terhadap guru dengan menggunakan pendekatan dan teknik supervisi yang tepat. 3. Menindaklanjuti hasil supervisi akademik terhadap guru dalam rangka peningkatan profesionalisme guru. Supervisi akademik diharapkan mampu mengembangkan kualitas guru serta mampu membuat situasi belajar mengajar yang lebih baik untuk membantu dalam pencapaian tujuan pendidikan sekolah, membantu guru dalam menyelesaikan permasalahan dalam pembelajaran, membimbing guru yang belum paham menggunakan media pembelajaran yang modern, serta membantu guru dalam menilai perkembangan siswa sehingga mutu pembelajaran yang diharapkan dapat terwujud dengan melalui adanya implementasi supervisi akademik oleh kepala sekolah (Sugiyanti dan Sabar2016:56). Taufik Ikbal (2017:69) mengemukakan bahwa Mutu pembelajaran memiliki lima konsep yaitu sebagai berikut :1. Kesuaian yaitu antar karakteristik antara peserta didik dengan strategi belajar mengajar yang diterapkan oleh guru. 2. Daya tarik guru dalam menciptakan suasana kelas yang akrab, hangat dan meransang pembentukan kepribadian peserta didik. 3. Efektivitas dalam pembelajaran melalui tahap perencanaan, pengembangan, pelaksanaan, penilaian dan penyempurnaan. 4. Efisiensi kesepadanan antara waktu, biaya, dan tenaga yang digunakan dengan hasil yang diperoleh. 5. Produktivitas pembelajaran dari menghafal dan mengingat ke menganalisis dan mencipta.

Dengan memperhatikan hal di atas, dapat kita lihat betapa pentingnya peran kepala sekolah dan guru dalam meningkatkan mutu pembelajaran. Kepala sekolah sebagai supervisor dalam mengelola pendidikan, termasuk dalam rangka peningkatan mutu pembelajaran yang ada di sekolah tersebut. Mutu pembelajaran merupakan hal pokok yang harus dibenahi dalam rangka peningkatan mutu pendidikan.Guru melalui arahan kepala sekolah sebagai supervisior menjadi titik fokusnya dalam proses pembelajaran, guru dituntut untuk memakai: metode, media, strategi dalam proses pembelajaran, sehingga dapat menghasilkan mutu dalam pembelajaran. 
A. Implementasi Supervisi Akademik dalam Peningkatan Mutu Pembelajaran

Supervisi merupakan proses pemberian bantuan kepada guru, secara bahasa supervisi terdiri dari dua kata yaitu super dan vision yang mempunyai arti penglihatan dari atas. Definisi tersebut bermakna bahwa yang memiliki kedudukan diatas melihat kebawah artinya orang yang memiliki kedudukan tinggi memberikan arahan terhadap bawahannya (Siti Fatimah 2015:141). Kepala sekolah memiliki peran penting dalam kegiatan sekolah.Kepala sekolah merupakan seorang pemimpin sekolah/manajer yang berada di level sekolah. Kedudukan kepala sekolah merupakan ujung tombak dalam pengelolaan pendidikan yang akan membawa dan menentukan arah gerak dari sekolah yang dipimpinnya. Maka kepala sekolah dituntut untuk memiliki kemampuan dan keterampilan dalam mengelola dan memberdayakan seluruh sumber daya pendidikan yang ada sehingga mampu dioperasionalkan guna mendukung terhadap program pendidikan yang direncanakan (Kusnandar 2012:102).

Seorang kepala sekolah harus selalu melakukan pengawasan kepada para guru agar guru tersebut tidak melakukan kesalahan atau penyimpangan ketika mereka bertugas. Kinerja guru dapat dikatakan baik dan memuaskan jika tujuan yang dicapai sesuai dengan standar yang telah ditetapkan di sekolah tersebut, dalam hal ini pengawasan yang dilakukan oleh kepala sekolah terhadap kinerja guru mempunyai peranan yang sangat penting karena jika kepala sekolah tidak melakukan pengawasan dalam arti lain membiarkan guru bekerja sesuai dengan keinginannya masing-masing maka kemungkinan besar tujuan yang akan dicapai akan jauh sekali dari standar yang telah ditetapkan (Ahmad Susanto 2016:240).

Dari uraian di atas jelas bahwa pelaksanaan supervisi kepala sekolah dimaksud adalah usaha-usaha yang diperlukan dalam membantu guru-guru agar semakin mampu mewujudkan proses belajar mengajar. Dengan demikian berarti juga bahwa supervisi kepala sekolah tidak ditunjukkan kepada siswa, kegiatan membantu siswa agar mampu melaksanakan proses belajar mengajar secara berdaya dan berhasil.

Pelaksanaan sepervisi kepala sekolah pada dasarnya merupakan kegiatan pembinaan personil, agar semakin mampu melaksanakan tugas-tugas yang termasuk dalam job description.Tujuan dari supervisi kepala sekolah dalam melaksankan tugastugasnya guna membantu yang bersangkutan melakukan perbaikan-perbaikan bilamana diperlukan, dengan menunjukkan kekurangan-kekurangan atau kelemahan masingmasing dalam bekerja. Dengan kata lain tujuan supervisi kepala sekolah adalah menumbuhkan kesadaran guru/pegawai untuk berusaha dengan kemampuan sendiri memperbaiki kekurangan atau kelemahannya dalam melaksanakan tugas berdasarkan hasil penilaian yang dilakukan kepala sekolah.

Menurut Ngalim Purwanto (2014:119) kegiatan atau usaha-usaha yang dapat dilakukan oleh kepala sekolah sesuai dengan fungsinya sebagai supervisor antara lain : 1. Membangkitkan dan meransang guru-guru dan pegawai sekolah didalammenjalankan tugasnya dan masing-masing dengan sebaik-baiknya. 2. Membina kerjasama yang baik, yang harmonis diantara guru-guru danpegawai sekolahnya. 3. Berusaha mempertinggi mutu dan pengetahuan guru-guru dan pegawaisekolah antara lain dengan mengadakan diskusi-diskusi kelompok, menyediakan perpustakaan sekolah, dan atau mengirim mereka untuk mengikuti penataran-penataran, seminar sesuai dengan bidangnya masing-masing.Membina hubungan kerjasama antara sekolah dengan komite sekolah dalam rangka meningktkan mutu pendidikan para siswa. 


\section{METODE PENELITIAN}

Penelitian ini menggunakan pendekatan deskriptif kualitatif. Penelitian kualitatif adalah sebuah strategi yang difokuskanpada pencarian makna, pemahaman, konsep, karakteristik, gejala,symbol dan gambaran fenomena yang ditargetkan, multimetode,natural dan menyeluruh, mengutamakan kualitas, menggunakan berbagai metode dan penyajian dalam bentuk naratif. Secara sederhana dapat dikatakan bahwa tujuan penelitian kualitatif adalah untuk mencari jawaban terhadapfenomena atau masalah melalui penerapan sistem prosedur ilmiah melalui metode kualitatif. (ShidiqdanChoiri2019:22)

Sumber Data Moloeng (2009:157) menjelaskan bahwa sumber data adalah dari mana data penelitian tersebut diperoleh sumber tersebut bisa berasal dari manusia dan non manusia. Sumber data manusia berfungsi sebagai subjek atau informasi, sedangkan non manusia berupa dokumen yang relevan dengan rumusan masalah penelitian, seperti: catatan atau tulisan yang ada kaitannya dengan fokus penelitian. Sumber data utama pada penelitian kualitatif adalah kata-kata dan tindakan. Selebihnya data tambahan seperti dokumen dan lain-lainnya.Teknik yang digunakan dalam menentukan sumber data. Metode penelitian kualitatif, sumber data dipilih secara purposive sampling. Purposive sampling adalah teknik pengambilan sumber data dengan pertimbangan tertentu, seperti orang tersebut dianggap paling tahu tentang apa yang peneliti harapkan (Sugiyono 2009:300). Dalam penelitian ini peneliti menggunakan jenis data kualitatif dari sumber primer dan sumber sekunder:

\section{a. Sumber Primer}

Sumber primer adalah sumber data yang secara langsung memberikan data kepada pengumpul data. Data tersebut diperoleh dengan melakukan wawancara kepada responden atau informan. Pengamblilan responden yang dijadikan informan dilakukan secara purposive artinya teknik penentuan sampel dengan pertimbangan tertentu (Sugiyono 2009:124). Sedangkan yang dijadikan sumber primer adalah kepala sekolah dan guru yang faham terhadap masalah yang akan diteliti. Data Primer menurut Sumadi (2009:91) adalah data yang diperoleh secara langsung dari subjek penelitian dengan menggunakan alat pengukuran /alat pengambilan data langsung kepada subjek sebagai sumber informasi yang dicari.Sumber data primer pada penelitian ini yaitu Kepala Sekolah dan Guru di SMA Sekecamatan Simpang Pematang Kabupaten Mesuji (SMA Negeri 1 Simpang Pematang, SMA Negeri 2 Simpang Pematang dan SMA Islam Terpadu Daar El Fikri) berkenaan dengan masalah yang diteliti.

\section{b. Sumber Sekunder}

Data sekunder yaitu data yang tidak langsung memberikan data kepada pengumpul data.Data ini diperoleh dari data-data dokumentasi berupa profil serta dokumen-dokumen lain yang bisa dijadikan sumber data dalam penelitian ini. Menurut Sugiyono (2009:225) sumber sekunder adalah yang tidak langsung memberikan data kepada pengumpul data, misalnya lewat orang lain atau lewat dokumen. Adapun sumber data sekunder merupakan data yang tidak langsung memberikan data kepada pengumpul data, misalnya melalui dokumentasi atau melalui orang yang tidak terlibat langsung dalam ruang lingkup yang akan diteliti. Data pendukung yang diperoleh secara tidak langsung dari sumbernya. Data ini peneliti ambil melalui guru-guru atau karyawan di Guru di SMA Sekecamatan Simpang Pematang Kabupaten Mesuji (SMA Negeri 1 Simpang Pematang, SMA Negeri 2 Simpang Pematang dan SMA Islam Terpadu Daar 
El Fikri), dokumen atau laporan yang telah tersusun dalam arsip yang tidak dipublikasikan, buku-buku, surat kabar, internet dan lain-lain.

Dalam penelitian kualitatif terdapat tiga teknik pengumpulan data,yaitu wawancara, dokumentasi dan observasi. Dalam penelitian ini, teknik pengumpulan data primer menggunakan metode wawancara tidak terstruktur, yang dilakukan dengan cara membuat pedoman wawancara yang hanya memuat garis besar pertanyaan yang akan diajukan kepada orang-orang yang berkompeten dalam kajian yang akan peneliti lakukan di Guru di SMA Sekecamatan Simpang Pematang Kabupaten Mesuji (SMA Negeri 1 Simpang Pematang, SMA Negeri 2 Simpang Pematang dan SMA Islam Terpadu Daar El Fikri, antara lain; kepala sekolah dan guru.

\section{a. Wawancara}

Secara definitif wawancara adalah tanya jawab antara pewawancara dan yang diwawancarai untuk meminta keterangan ataupendapat mengenai suatu hal. Wawancara sering juga disebut dengan kuesioner lisan, adalah sebuah dialog yang dilakukan oleh pewawancara (interviewer) untuk memperoleh informasi dari wawancara.

Wawancara digunakan oleh seorang peneliti untuk menilai keadaan seseorang.Secara fisik teknik wawancara dapat dibedakan atas wawancara terstruktur dan tidak terstruktur.Dalam penelitian ini peneliti menggunakan wawancara terstruktur. Wawancara terstruktur adalah teknik wawancara di mana peneliti menyiapkan daftar pertanyaan sehingga proses wawancara akan terarah dengan baik.

Instrumen yang peneliti gunakan dalam penelitian ini berupa pertanyaanpertanyaan untuk wawancara yang digunakan untuk menggali informasi tentang Implementasi supervisi akademik kepala sekolah dan pertanyaan-pertanyaan yang menyangkut Mutu Pembelajaran. Peneliti melakukan wawancara terhadap kepala sekolah dan guru Guru di SMA Sekecamatan Simpang Pematang Kabupaten Mesuji (SMA Negeri 1 Simpang Pematang, SMA Negeri 2 Simpang Pematang dan SMA Islam Terpadu Daar El Fikri). Wawancara yang dilakukan oleh peneliti adalah untuk memperoleh data yang lebih valid. Adapun pedoman wawancara terlampir.

\section{b. Metode Dokumentasi}

Dokumentasi berasal dari dokumen yang berarti barang-barang tertulis. Dalam menggunakan metode dokumentasi ini, peneliti menyelidiki benda-benda tertulis seperti buku-buku, majalah, dokumen, peraturan-peraturan notulen rapat, catatan harian dan sebagainya. Di sisi lain dokumen lebih bersifat personal, mencakup buku harian(diares), memo (memos), surat (letters), catatan lapangan (field notes), dan sebagainya. Sedangkan pendokumentasian yang dilakukan peneliti adalah berupa catatan-catatan, notulen rapat, foto-foto, dokumen hasil supervise kepala sekolah dan data dokumen lain yang berkaitan dengan supervisi akademik kepala sekolah.

\section{c. Observasi}

Di samping wawancara, penelitian ini juga melakukan metode observasi. Observasi adalah pengamatan dan pencatatan secara sistematik terhadap unsur-unsur yang tampak dalam suatu gejala atau gejala-gejala dalam objek penelitian. Metode observasi adalah metode pengumpulan data yang digunakan untuk digunakan untuk menghimpun data penelitian melalui pengamatan dan penginderaan.Dalam penelitian ini observasi dibutuhkan untuk dapat memahami proses terjadinya wawancara dan hasil 
wawancara dapat dipahami dalam konteksnya. Observasi yang akan dilakukan adalah observasi terhadap subjek, perilaku subjek selama wawancara, interaksi subjek denganpeneliti dan hal-hal yang dianggap relevan sehingga dapat memberikan data tambahan terhadap hasil wawancara. Beberapa hal yang perlu diperhatikan dalam observasi adalah topografi, jumlah dan durasi, intensitas atau kekuatan respon, stimulus kontrol (kondisi dimana perilaku muncul), dan kualitas perilaku.Observasi dalam penelitian ini digunakan untuk mengamati seluruh kegiatan yang dilakukan kepala sekolah tentang supervisi.

Teknik analisis data yang dipergunakan dalam penelitian kualitatif adalah model analisis dan mengalir (flow model). Langkah-langkah yang dipergunakan dalam model ini antara lain: pengumpulan data, reduksi data, penyajian data dan penarikan kesimpulan. Pengumpulan Data Peneliti membuat catatan data yang dikumpulkan melalui observasi, wawancara dan studi dokumentasi yang merupakan catatan lapangan yang terkait dengan pertanyaan atau tujuan penelitian. Proses analisa data dimulai dengan menelaah seluruh data yang tersedia dari berbagai sumber, yakni dari observasi, wawancara dan studi dokumentasi. Setelah dibaca dan dipelajari, maka langkah selanjutnya adalah mengadakan reduksi data. Langkah ini berkaitan erat dengan proses menyeleksi, memfokuskan, menyederhanakan, mengabstraksikan dan mentransformasikan data mentah yang diperoleh dari hasil penelitian. Reduksi data dilakukan selama penelitian berlangsung, langkah ini dilakukan sebelum data benarbenar dikumpulkan. Peneliti sudah mengetahui data-data apa saja yang dilakukan terkait Penyajian data atau sekumpulan informasi yang memungkinkan peneliti melakukan penarikan kesimpulan. Bentuk penyajian data yang umum dilakukan dalam penelitian kualitatif adalah teks naratif yang menceritakan secara panjang lebar temuan penelitian.

Penarikan kesimpulan atau verikasi merupakan langkah selanjutnya. Analisnya menggunakan analisis model interaktif. Artinya analisis ini dilakukan dalam bentuk interaktif dari ketiga komponen utama tersebut.Data yang terkumpul dari hasil observasi, wawancara dan studi dokumen yang terkait dengan penelitian direduksi untuk dipilih mana yang paling tepat untuk disajikan. Proses pemilihan data akan difokuskan pada data yang mengarah untuk pemecahan masalah, penemuan, pemaknaan, atau untuk menjawab pertanyaan penelitian. Teknik pemeriksaan keabsahan data yang digunakan dalam penelitian ini adalah teknik Triangulasi. Menurut Lexy J. Moleong (2012:330) "triangulasi adalah teknik pemeriksaan keabsahan data yang memanfaatkan sesuatu yang lain diluar data itu untuk keperluan pengecekan atau sebagai pembanding terhadap data itu". Denzin membedakan empat macam triangulasi sebagai teknik pemeriksaan yang memanfaatkan penggunaan sumber, metode, penyidik dan teori.

Dalam penelitian ini peneliti menggunakan teknik pemeriksaan keabsahan data triangulasi dengan sumber dan triangulasi dengan metode menurut Patton triangulasi dengan sumber "berarti membandingkan dan mengecek balik derajat kepercayaan suatu informasi yang diperoleh melalui waktu dan alat yang berbeda dalam penelitian kualitatif'. Sedangkan triangulasi dengan metode menurut Patton terdapat dua strategi, yaitu (1) pengecekan derajat kepercayaan penemuan hasil penelitian beberapa teknik pengumpulan data dan (2) pengecekan derajat kepercayaan beberapa sumber data dengan metode yang sama. 
Dengan teknik triangulasi dengan sumber, peneliti membandingkan hasil wawancara yang diperoleh dari masing-masing sumber atau informan penelitian sebagai pembanding untuk mengecek kebenaran informasi yang didapatkan.Selain itu peneliti juga melakukan pengecekan derajat kepercayaan melalui teknik triangulasi dengan metode, yaitu dengan melakukan pengecekan hasil penelitian dengan teknik pengumpulan data yang berbeda yakni wawancara, observasi, dan dokumentasi sehingga derajat kepercayaan data dapat valid.

\section{HASIL DAN PEMBAHASAN}

Berdasarkan paparan data dari hasil wawancara dan observasi yang dilakukan terhadap kepala sekolah atau yang mewakili di SMA Se-Kecamatan Simpang Pematang Kabupaten Mesuji, maka selanjutnya dapat dibuat temuan penelitian terhadap implemntasi supervisi akademik kepala sekolah terhadap peningkatan mutu pembelajaran di SMA Se-Kecamatan Simpang Pematang sebagai berikut:

Kepala sekolah merupakan pejabat fungsional dan profesional dalam organisasi sekolah yang bertugas untuk mengatur semua sumber daya sekolah serta mendayagunakanya dengan melibatkan guru-guru, staf, serta pegawai lainnya yang ada di sekolah dalam rangka membimbing dan mendidik peserta didik untuk mengoptimalkan potensinya sesuai dengan tujuan pendidikan. Kepala sekolah bersama dengan guru erat hubungannya dalam menciptakan mutu pembelajaran. Pembelajaran bermutu yaitu pembelajaran yang mampu membuat siswa aktif, kreatif dan inovatif serta memberikan perubahan positif kepada siswanya.

Pembelajaran mempunyai dua karakteristik, yaitu : Pertama, dalam proses pembelajaran melibatkan proses berfikir. Kedua, dalam proses pembelajaran membangun suasana dialogis dan proses tanya jawab terus menerus yang diarahkan untuk memperbaiki dan meningkatkan kemampuan berfikir siswa, yang pada gilirannya kemampuan berfikir itu dapat membantu siswa untuk memperoleh pengetahuan yang mereka konstruksi sendiri.

Proses pembelajaran yang baik seharusnya dapat dilakukan oleh siswa baik di dalam maupun di luar kelas, dan dengan karakteristik yang dimiliki oleh siswa diharapkan mereka mampu menerima dan merespon dengan baik pembelajaran yang telah diberikan. Hal ini tentunya perlu didukung pula oleh sumber daya guru yang professional dalam mengajar. Supervisi akademik merupakan upaya untuk membantu guru-guru mengembang-kan kemampuannya dalam mencapai tujuan pembelajaran. Dengan demikian, esensi supervisi akademik itu sama sekali bukan menilai kinerja guru dalam mengelola proses pembelajaran, melainkan membantu guru mengembangkan kemampuan profesionalismenya.

Implementasi Supervisi Akademik Kepala Sekolah untuk Mewujudkan Mutu Pembelajaran yang ada di SMA Se-Kecamatan Simpang Pematang Kabupaten Mesuji; Kegiatan supervisi harus dilaksanakan secara terjadwal dan secara rutin. Tujuan dari supervisi yang dilaksanakan secara terjadwal adalah untuk terus meningkatkan kompetensi yang telah dimiliki oleh guru yang disupervisi serta untuk meningkatkan kualitas pembelajaran di kelas maupun di luar kelas yang akan berdampak pada terwujudnya mutu pendidikan. Berdasarkan keterangan di atas berikut tahapan kegiatan 
supervisi akademik untuk meningkatkan mutu pembelajaran yang ada di SMA SeKecamatan Simpang Pematang Kabupaten Mesuji, diawali dengan perencanaan, pelaksanaan dan tindak lanjut hasil supervisi.

1. Perencanaan Program Supervisi Akademik Untuk Meningkatkan Mutu Pembelajaran Semua kepala sekolah di SMA Se-Kecamatan Simpang Pematang Kabupaten Mesuji mengatakan bahwa perencanaan program supervisi akademik diawali dengan membentuk tim supervisi, yang mana tim tersebut bertugas untuk merumuskan tujuan supervisi, menentukan sasaran supervisi dan membuat jadwal pelaksanaan supervisi akademik tersebut. Dokumen tersebut selanjutnya menjadi acuan atau instrumen bagi para kepala sekolah saat kegiatan supervisi berlangsung. Tim supervisi terdiri dari kepala sekolah dan waka kurikulum yang diberi surat tugas untuk membantu melaksanakan supervisi akademik. Tim supervisi yang dibentuk selanjutnya merumuskan tujuan supervisi akademik, menentukan sasaran supervisi akademik, dan membuat jadwal supervisi, serta mempelajari instrumen supervisi yang akan digunakan dalam monitoring. Tim supervisi menuangkan rumusan tujuan, sasaran, jadwal, dan instrumen pada program supervisi akademik. Dokumen tersebut akan menjadi dasar dan acuan kepala sekolah dan tim supervisi untuk melaksanakan supervisi akademik.

Tim supervisi merumuskan tujuan supervisi akademik, kemudian membuat jadwal dan mempelajari instrumen atau lembar pengamatan yang akan digunakan pada saat supervisi dilaksanakan. Kepala sekolah dan tim supervisi melaksanakan supervisi akademik dengan menggunakan instrumen penilaian sebagai acuan untuk menilai kinerja guru. Hal ini sejalan dengan Peraturan Menteri Pendidikan Nasional Nomor 13 Tahun 2007 Tentang Standar Kepala Sekolah yang dinyatakan bahwa salah satu kompetensi Kepala Sekolah adalah memiliki kompetensi dalam merencanakan program supervisi akademik dalam meningkatkan profesional guru. Supervisi akademik dengan menggunakan instrumen penilaian sebagai acuan untuk menilai kinerja guru baik pada bidang administrasi maupun proses kegiatan belajar mengajar di dalam maupun di luar kelas. Pada bidang administrasi, aspek yang dinilai yaitu pada perangkat pembelajaran seperti program tahunan, program semester, silabus, RPP, dan penilaian. Sedangkan pada kegiatan proses belajar mengajar dinilai mulai dari kegiatan awal, kegiatan inti, dan kegiatan penutup.

2. Pelaksanaan Supervisi Akademik Kepala Sekolah dengan Menggunakan TeknikTeknik Supervisi Untuk Meningkatkan Mutu Pembelajaran

Pelaksanaan supervisi yang dilakukan kepala sekolah di SMA Se-Kecamatan Simpang Pematang Kabupaten Mesuji diawali dengan mengadakan pertemuan awal untuk menetapkan kegiatan supervisi, serta melakukan kunjungan dan observasi terhadap pelaksanaan pembelajaran di kelas maupun di luar kelas dan diakhiri dengan melakukan pembahasan terhadap temuan yang didapat dari observasi yang dilakukan di dalam kelas. kepala sekolah telah cukup baik dalam menerapkan pendekatan langsung dan pendekatan tidak langsung. Pendekatan langsung sebenarnya ditunjukkan dengan kepala sekolah yang aktif mendekati guru untuk mengetahui kendala guru dalam pembelajaran dan bagaimana solusi serta cara meningkatkan mutu pembelajaran. Selain itu, kepala sekolah meng-agendakan rapat kepada guru mengenai metode pembelajaran. Selanjutnya, pendekatan tidak langsung ditunjukkan oleh guru yang kadang-kadang melaksanakan konsultasi dengan kepala sekolah apabila menemukan kendala dalam proses pembelajaran. 


\section{Menindaklanjuti Hasil Supervisi Akademik untuk Meningkatkan Mutu Pembelajaran}

Kepala sekolah di SMA Se-Kecamatan Simpang Pematang Kabupaten Mesuji melakukan analisis hasil supervisi akademik untuk mengetahui langkah apa yang akan dilaksanakan selanjutnya terhadap guru. Selain itu, hasil analisis akan dijadikan sebagai bahan pertimbangan kepala sekolah untuk melakukan evaluasi terhadap guru. Tindak lanjut dilakukan diantaranya dengan beberapa hal yaitu membimbing guru dalam pelaksanaan kurikulum di sekolah, mengadakan pertemuan atau rapat, mengadakan diskusi kelompok dan mengadakan penataran-penataran.

Selanjutnya kepala sekolah juga memberikan motivasi kepada guru, yang mana hal ini bila kita amati berkenaan dengan tahap pertemuan akhir, dimana didalamnya terjadi intraksi dalam hal pengevaluasian dan pemberian motivasi kepada guru demi perbaikan kinerja untuk masa-masa mendatang. Tindak lanjut dilakukan diantaranya dengan beberapa hal yaitu membimbing guru dalam pelaksanaan kurikulum di sekolah, mengadakan pertemuan atau rapat, mengadakan diskusi kelompok dan mengadakan penataran-penataran. kepala sekolah dalam melakukan evaluasi hasil supervisi akademik dengan melibatkan guru, kemudian secara bersama-sama mencari solusi terhadap masalah yang sifatnya umum sehingga masalah yang ada dapat terpecahkan. Analisis hasil supervisi akademik dilakukan kepala sekolah bersama guru dengan menganalisa secara bersama-sama hasil supervisi akademik yang dilaksanakan. Hal ini dibuktikan dengan adanya kegiatan kepala sekolah berupa diskusi secara personal dengan guru-guru dan program kegiatan rapat..

\section{KESIMPULAN}

Berdasarkan tujuan dari hasil penelitian data pembahasan tentang implementasi supervisi akademik kepala sekolah terhadap mutu pembelajaran di SMA Se-Kecamatan Simpang Pematang Kabupaten Mesuji sebagaimana yang telah dijelaskan pada bab-bab sebelumnya maka peneliti menyimpulkan bahwa: (1) Pelaksanaan supervisi akademik kepala sekolah telah dilaksanakan dengan cara kepala sekolah merencanakan program supervisi akademik dengan membuat tim supervisi yang diberi tugas untuk membuat tujuan supervisi akademik dan membuat jadwal supervisi akademik. (2) Kepala sekolah melaksanakan supervisi akademik terhadap guru dengan menggunakan pendekatan dan teknik supervisi seperti melakukan kunjungan kelas untuk mengamati pelaksanaan kegiatan belajar mengajar, mengamati aktivitas guru dalam mengajar, mengamati penguasaan guru terhadap bahan ajar, kepala sekolah melakukan diskusi secara individual dan kelompok terhadap guru- guru untuk membicarakan kurikulum belajar siswa. (3) Kepala sekolah menindak lanjuti hasil supervisi akademik terhadap guru dengan membahas mengenai metode pembelajaran, penggunaan dan teknik penilaian, penggunaan media pembelajaran dan penggunaan waktu dalam pembelajaran. Kepala sekolah juga melakukan analisis hasil supervisi akademik dilakukan kepala sekolah bersama guru menganalisa secara bersama hasil supervisi akademik yang dilaksanakan kepala sekolah sewaktu melaksanakan pengamatan atau monitoring dan pemantauan saat kunjungan atau observasi kelas, selanjutnya hasil supervisi akademik akan dijadikan dasar pertimbangan dan dimanfaatkan kepala sekolah untuk melakukan pembinaan terhadap guru. 


\section{DAFTAR PUSTAKA}

Cahyana, Ade. (2010). Upaya Meningkatkan Mutu Sekolah Melalui Otonomi Satuan Pendidikan. Jurnal Pendidikan dan Kebudayaan. Vol 16 No 2 Hal 109-117.

Dahlim. (2021). Upaya Meningkatan Mutu Pembelajaran Melalui Supervisi Akademik dan Bimbingan Berkelanjutan. Jurnal Teaching. Vol. 1. No. 2 Hal 109-113.

Djafri, Novianty. (2016). Manajemen Dan Kepemimpinan Kepala Sekolah. 2nded. Yogyakarta: Deepulish Publisher.

Danim, Sudarwan. (2006). Visi Baru Manajemen Sekolah: Dari Unit Birokrasi ke Lembaga Akademik. Bumi Aksara. Jakarta.

Darmadi, Hamid. (2010). Kemampuan Dasar Mengajar. Alfabeta. Bandung.

Daryanto, dan Rachmawati, Tutik. (2015). Supervisi Pembelajaran. Gava Media. Yogyakarta.

Depdiknas. (2004). Peningkatan Kualitas Pembelajaran. Depdiknas. Jakarta.

Direktorat Jenderal Pendidikan Dasar dan Menengah. (2017). Panduan Supervisi Akademik. Kementerian Pendidikan dan Kebudayaan. Jakarta.

Fattah, Nanang. (2012). Sistem Penjaminan Mutu Pendidikan. Remaja RosdaKarya. Bandung.

Fatimah, Siti., Irma Rosyidah. (2021). Implementasi Supervisi Akademik Kepala Madrasah Dalam Meningkatkan Mutupendidik Di MTS Sa Miftahul Hikmah Parengan Tuban. Jurnal Scaffolding. Vol. 3, No. 1. Hal 66-75.

Masdinar. (2021). Implementasi Supervisi Akademik Kepala Madrasah dalamMeningkatkan Mutu Pembelajaran Kooperatif di Madrasah Ibtidaiyah DDI Banga-banga Kabupaten Baru. Jurnal Edukasi Saintifik. Vol 1 No 2 Hal. 118126.

Upik Saryati. (2021). Pelaksanaan Supervisi Akademik Dalam Meningkatkan Mutu Pembelajaran di SD Negeri 78 Kota Bengkulu Tahun Pelajaran 2019/2020. Jurnal Lateralisasi. Vol 9 No 1 Hal 72-86. 